\title{
Influence of Social Factors on the Reproduction of Human Capital
}

\author{
Submitted $11 / 02 / 19,1^{\text {st }}$ revision 10/03/19, accepted 16/04/19 \\ I.N. Sycheva ${ }^{1}$, E.V. Skripleva ${ }^{2}$, A.N. Dunets ${ }^{3}$, \\ T.M. Vorozheykina ${ }^{4}$, I.N. Luzenina ${ }^{5}$, S. V. Khoruzhaya ${ }^{6}$
}

\begin{abstract}
:
Purpose: Exploring the problems of human capital formation at the present stage of development of the Russian economy, the authors consider it expedient to analyze the theory and practice of the influence of socio-economic factors on the formation of personnel potential.

Design/Methodology/Approach: The following methods were used by the authors: historical, statistical-economic, monographic.

Findings: The authors revealed that the quality of life and income level is more reflected in the desire of the population to choose as a permanent place of residence - rural areas.

Practical implications: The analysis of incomes as a fundamental factor influencing the formation of human capital indicates that considerable human capital has been formed in the agricultural sector, which is not fully utilized due to the low material interest of the rural population.

Originality/Value: The article discusses a number of factors influencing the formation of human capital in agriculture. The authors indicated that the level of wages depends on the geographical distance of the regions from the federal center and climatic conditions.
\end{abstract}

Keywords: Agriculture, quality of life, wages, the minimum wage, human potential, rural population, human capital.

JEL Classification: $Q 18, O 15$.

Paper type: Research article.

\footnotetext{
${ }^{1}$ I.I. Polzunov Altai state technical university, Barnaul, Russia, madam.si4eva2010@yandex.ru

${ }^{2}$ Southwest State University, Kursk, Russia

${ }^{3}$ Altai state University, Barnaul, Russia.

${ }^{4}$ The Financial University under the Government of the Russian Federation, Russian State Agrarian University - Moscow Agricultural Academy named after K.A. Timiryazev, Moscow, Russia

${ }^{5}$ Saratov Social and Economic Institute (branch) Plekhanov Russian University of Economics, Moscow, Russia

${ }^{6}$ Kuban State Agrarian University named after I.T. Trubilin, Krasnodar, Russia
} 


\section{Introduction}

Today, the economic situation of agriculture remains in crisis, regardless of the fact that the Government of the Russian Federation has taken a number of appropriate measures to maintain it. The implementation of the State Program for the Development of Agriculture for the period 2013-2020 undoubtedly requires significant investments and the development of measures for the formation of personnel security of the agricultural sector. The reform of economic relations that has been taking place in Russia over the past decade has affected all aspects of social and labor relations, including the issues of wage differentiation of various groups of workers. A further increase in agricultural production should be carried out in the presence of all productive resources, such as land, labor and capital.

At present, wages are formed under the influence of institutional and geographical factors: quality of life, level of education of the population, individual abilities of workers, as well as distance from the regional and federal center. In turn, the relationship between these factors in a planned and market economy are fundamentally different in nature. In accordance with market conditions, the wages of most workers in the current conditions are determined by their marginal productivity, which can be increased by accumulating human capital, including knowledge, skills and abilities (Stadnik, 2015).

\section{Literature review}

In economically developed countries, the role of human capital as a factor in the differentiation of wages is one of the most important areas of economic and labor research. Their results are widely represented in the works of T. Schulz and G. Becker. The contribution to the development of the theory of human capital consisted in the fact that T. Schulz formulated the definition according to which by human capital he understood "the form of capital that serves as a source of future earnings or future satisfaction, or both of them taken together. And he becomes human because he is an integral part of man" (Schulz, 1960). Thanks to Becker, economists began to consider spending on education as an investment that could generate revenue in the future. Gary Becker as human capital understood the totality of innate abilities and acquired knowledge, skills and motivations, the effective use of which contributes to an increase in income and other benefits (Becker, 1964).

\section{Methodology}

The subject of study is the economic and social relations associated with the formation of incomes of agricultural workers. The methodological basis of the research is the theoretical and methodological conclusions and statements of economic theory in general, as well as the works of economists on the formation of human capital in agriculture. Information base of the research is official statistical 
information provided by the Federal State Statistics Service of the Russian Federation and its territorial body in the Novosibirsk region. In the course of data processing and analysis, statistical methods, a monographic method, a method of analysis and comparison, etc. were used.

\section{Results}

The past few decades, agriculture is experiencing serious economic and demographic problems. Personnel starvation in agriculture is manifested in the fact that, first of all, there is an aging professional staff, and an insufficient level of qualification of managers and specialists leads to an inefficient use of agricultural innovations, which in turn reduces the economic efficiency of the agricultural organization (Shelkovnikov et al., 2018; Smirnov et al., 2017). The Novosibirsk region, which possesses all the necessary resources, faces the acute problem of providing food through its own production. Food security of the region is the most important indicator of the standard of living of the population.

The term "human capital" begins its existence from the time of Plato and Aristotle. John Stuart Mill, in his book Fundamentals of Political Economy, writes: "I don't regard man myself as wealth. But his acquired abilities, which exist only as a means and are generated by labor, with good reason, we believe, fall into this category. And further: "The craftsmanship, energy and perseverance of the country's workers are as much considered its wealth, as are their tools and machines." (Mill, 1980). More precisely, human capital is determined by B.M. Genkin: "Human capital as a set of qualities that determine productivity and can become sources of income for a person, family, enterprise, and society. These qualities are usually considered health, natural abilities, education, professionalism, mobility (Genkin, 2003).

According to B.P. Pankov, the following features of human capital in agriculture stand out:

- formation of the supply of labor mainly on the demographic potential of a limited territory in the context of the unfavorable development of demographic processes; - low horizontal and vertical labor mobility, due to the underdeveloped housing market, unequal social and infrastructural living conditions in different rural areas, attachment to their own economy, home, fellow villagers, terrain;

- poor awareness of labor market subjects about the demand for labor, about its price in various territorial market segments, often even within the boundaries of one municipality;

- significantly lower, compared with the urban labor market, the density of labor and jobs per unit territory;

- limited territorial availability of jobs, due to the underdevelopment of road and transport infrastructure; 
- low price of labor in agriculture, which is associated with the specifics of its formation: low elasticity of demand and high elasticity of prices for agricultural products, low profitability of the industry;

- lower quality of labor resources in comparison with the city;

- seasonal labor needs;

- limited areas of application of labor;

- large compared with the city duration of unemployment, its growing into stagnant in depressed rural areas (Pankov, 2006)

The reluctance of young and ambitious specialists after receiving higher agricultural education to return to rural areas is due to many reasons. One of the main problems is the low material interest of workers in this industry (Romanov and Nikulin, 2016; Dashko and Lange, 2017; Kuznetsova et al., 2018). In view of the above, it can be concluded that the main factors influencing the formation of human capital are:

- demographic and migration processes occurring in rural areas;

- income level in rural areas;

- the state of the labor market in rural areas;

- the level of development of the rural health care system;

- level of education of the rural population;

- development of social and cultural infrastructure in rural areas.

In this study, a group of authors analyzed the incomes and quality of life of the rural population as a determining factor influencing the formation of human capital in rural areas (Shelkovnikov et al., 2016). So, the main source of income for the overwhelming majority of the population is wages. Salary performs a number of specific functions:

1. The reproductive function of wages is that it must be sufficient to ensure the expanded reproduction of labor power;

2. Stimulating - wages stimulate the involvement of people in the labor process, its effective performance and advanced training;

3. Distribution - the value of wages ensures the distribution of workers in jobs;

4. Accounting - with the help of wages, control is exercised over the measure of labor and the value of its payment;

5. Social - helps to ensure the living standards of not only the employees themselves, but also disabled members of their families.

In turn, a number of scientists considered wages from different positions. So, R.Z. Livshits divided the wages into parts, singling out the tariff system as the basic wage - "a set of tariff rates, official salaries, supplements and allowances, district coefficients. It reflects the qualifications of labor, working conditions, the importance of the industry. The tariff system is the main tool ... of wage policy " (Korshunov, 1974). M.E. Pankin called parts of wages differently: constant, which is the tariff system, and the variable, which includes bonuses, remuneration for the 
annual results of the enterprise, etc. Similarly, these parts of wages in modern scientific and educational literature (Korshunov, 1974). The size of the average wage in all types of economic activity in the Novosibirsk Region is significantly lower than that in the Russian Federation as a whole (Rudoy et al., 2015). There is a noticeable significant differentiation in wages in various sectors of economic activity. The most paid type is financial activity and mining (Figure 1).

Figure 1. Average wages by economic activity, for 2017, rub.

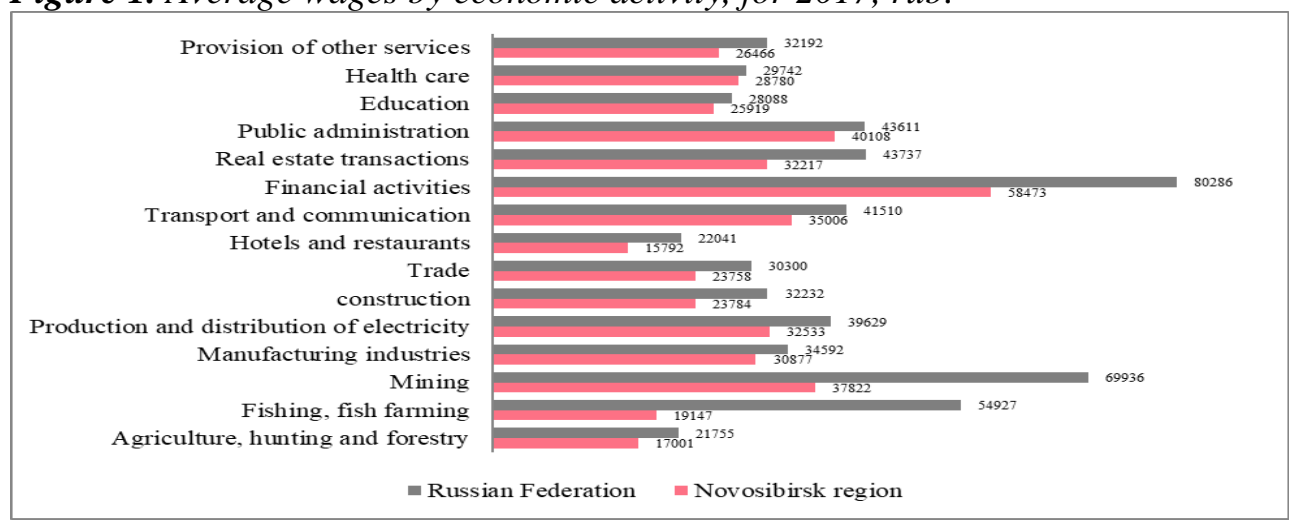

The least paid areas of activity are restaurant business - 15792.7 thousand rubles. and agricultural sector -17001 thousand rubles. In 2017, the lag on this indicator was as follows: financial activity - 21,635 rubles, or $37.5 \%$; mining and quarrying 32111 rubles, or 84\%; education - 20169 rubles, or 8.3\%; fishing and fish farming 35,780 rubles, or $186 \%$; agriculture -4754 rubles, or $27.9 \%$ of the average Russian level. Despite the fact that the size of the average wage in different regions of the Siberian Federal District shows a positive trend, the lag in income is observed absolutely in all regions of the Siberian Federal District. The first place in the average wage is observed in the Krasnoyarsk Territory (40,929 rubles), the second place is the Tomsk Region (38,388 rubles), the third place is the Irkutsk Region (37587 rubles).

The main reason for the decline in real income is a decrease in the growth of their nominal level. Table 1 shows that over the past three years, real incomes of the population have fallen by more than $10 \%$. This is caused by a significant increase in prices for consumer goods (Table 1). For 2012-2017 the subsistence minimum in the Novosibirsk region doubled and began to be 11,159 rubles. Do not forget that the most important indicators of measuring incomes of the population currently are indicators such as the cost of living and the minimum wage. Under the subsistence minimum we mean the value sufficient to ensure the normal functioning of the human body and preserve its health, a set of food products, as well as the minimum set of non-food goods and services necessary to meet the basic social and cultural needs of the individual. 
Figure 2. The average wage in the Siberian Federal District, rub.

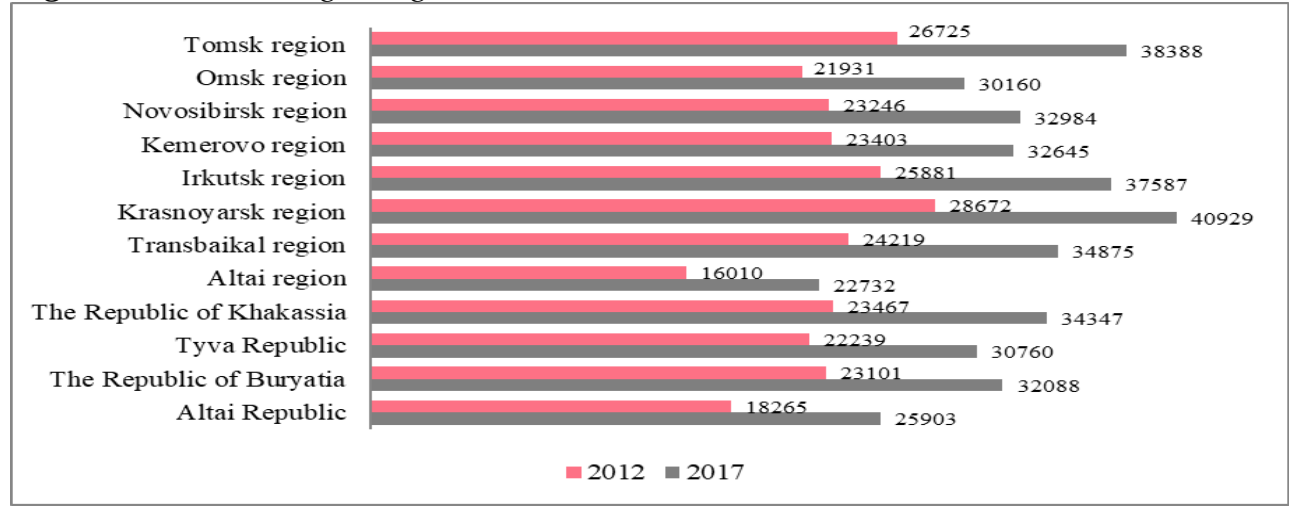

Table 1. Nominal and real incomes of the population in the Novosibirsk region

\begin{tabular}{|c|c|c|c|c|c|c|c|c|}
\hline \multirow[t]{2}{*}{ Indicators } & \multicolumn{8}{|l|}{ Years } \\
\hline & 2010 & 2011 & 2012 & 2013 & 2014 & 2015 & 2016 & 2017 \\
\hline $\begin{array}{l}\text { Average monthly } \\
\text { nominal accrued } \\
\text { wages } \\
\text { employees for the } \\
\text { year in the whole } \\
\text { economy }\end{array}$ & 20952 & 23369 & 26629 & 29792 & 32867 & 34030 & $\begin{array}{l}3670 \\
9\end{array}$ & 39167 \\
\hline $\begin{array}{l}\text { Real average } \\
\text { monthly salary, \% } \\
\text { of previous year }\end{array}$ & 105,2 & 102,8 & 108,4 & 104,8 & 101,2 & 91,0 & $\begin{array}{l}100, \\
8\end{array}$ & 102,9 \\
\hline
\end{tabular}

Since 2015, there has been a marked increase in the number of people with incomes below the subsistence minimum. The average wage in the agricultural sector is half that of the average for the economy. It must be borne in mind that the real wages of agricultural workers are significantly lower and, in fact, do not exceed the subsistence minimum in the region. The above allows us to conclude that this amount of money is not enough for a full life of workers and their families. The lowest level of per capita income is mostly observed in rural areas. Below the poverty line is almost every fifth person in rural areas, while $53 \%$ are people of working age. The proportion of children is $48 \%$, pensioners - 3\% (Table 2).

Table 2. Incomes of the population of the Novosibirsk region, rub.

\begin{tabular}{|l|l|l|l|l|l|l|}
\hline \multirow{2}{*}{ Indicators } & \multicolumn{7}{|l|}{ Years } & \multicolumn{7}{l|}{} \\
\cline { 2 - 7 } & 2012 & 2013 & 2014 & 2015 & 2016 & 2017 \\
\hline Subsistence minimum & 6989 & 7764 & 8945 & 10117 & 10583 & 11159 \\
\hline - able-bodied population & 7565 & 8274 & 9530 & 10759 & 11233 & 11854 \\
\hline - pensioners & 5489 & 6270 & 7206 & 8153 & 8503 & 8950 \\
\hline - children & 7858 & 9086 & 10363 & 9030 & 10965 & 11545 \\
\hline Minimum wage & 4611 & 5205 & 5554 & 5965 & 7500 & 7800 \\
\hline Pension & 8998 & 9838 & 10677 & 11859 & 17199 & 13086 \\
\hline $\begin{array}{l}\text { The share of the population with } \\
\text { incomes below is the minimum of the }\end{array}$ & 10 & 10,8 & 11,2 & 13,3 & 13,3 & 13,6 \\
\hline
\end{tabular}




\begin{tabular}{|l|l|l|l|l|l|l|}
\hline Russian Federation, \% & & & & & & \\
\hline $\begin{array}{l}\text { The proportion of the population with } \\
\text { incomes below the subsistence } \\
\text { minimum, } \%\end{array}$ & 14,1 & 14,4 & 15,2 & 18,3 & 17,0 & 17,2 \\
\hline $\begin{array}{l}\text { Average salary in the Russian } \\
\text { Federation }\end{array}$ & 26909 & 29940 & 32495 & 34030 & 36706 & 39085 \\
\hline $\begin{array}{l}\text { The average wage in agriculture of the } \\
\text { Russian Federation }\end{array}$ & 13256 & 15125 & 17724 & 19721 & 21755 & 22368 \\
\hline Average salary in economics & 23245 & 25527 & 27231 & 27327 & 27513 & 32839 \\
\hline Average wages in agriculture & 11475 & 12892 & 14129 & 15724 & 17001 & 17187 \\
\hline
\end{tabular}

Against the background of a slowdown in wage growth and an increase (1.4 times) in the growth rate of the subsistence minimum of the working-age population, the purchasing power of wages declined in all municipal districts and urban districts of the Novosibirsk Region. Thus, under the conditions prevailing today, agriculture is the lowest paid industry, since the wages of agricultural workers are much lower than in other sectors of the economy. It follows that the gap in incomes of the population in the region complicates the socio-demographic situation of the development of the region, which in turn intensifies the depopulation of the population in rural areas (Stadnik, 2015).

\section{Conclusion}

An analysis of the incomes of the rural population showed that the existing level of incomes of workers in the industry is not sufficient to maintain the livelihoods of workers and their families. Such external factors as negative socio-economic situation and low material interest, which extremely adversely affect the involvement of young professionals in the industry, have a negative impact on the consolidation of workers in the industry. The above leads to a decrease in soil fertility, an increase in the degree of wear and tear of equipment, loss of ability to work and qualification of the workforce.

The analysis clearly confirmed that the reproduction of labor resources in rural areas is influenced by a number of factors, one of which is the remuneration of the population living in rural areas. It is worth noting that there were unresolved issues related to the differentiation of wages of workers depending on the sectoral affiliation of organizations. Separate attention should be paid to the consideration of subjective assessments of other wage determinants, such as work experience, the result of labor, as well as professional and gender affiliation. Further research in this direction will allow a much deeper understanding and assessment of the ongoing economic and social aspects of the influence of wages on the reproduction of human capital.

Thus, the innovative transformations of the Russian economy associated with the formation of the resource potential of the agricultural sector are of considerable relevance. This is due to the fact that for the successful implementation of the state 
program for the sustainable development of rural areas, special attention should be paid to the formation of human resources and the further consolidation of workers in rural areas.

\section{References:}

Dashko, R.E., Lange, I.Y. 2017. Engineering-geological aspects of negative consequences of contamination of dispersive soils by petroleum products. Journal of Mining Institute, 228, 624-630, DOI: 10.25515/PMI.2017.6.624.

Genkin, B.M. 2003. Economics and sociology of labor: studies. for universities. 5th ed., Ext. Moscow, p. 416.

Korshunov, Yu.N. 1974. Soviet labor legislation: Ref. book for professional. M., p. 203.

Kuznetsova, I., Voronkova, O., Bakvalov, S., Ruiga, I., Zhuruli, G., Levichev, V. 2018. Formation of Human Capital as a Key Factor in Ensuring the National Security of Agriculture in the Digital Economy. European Research Studies Journal, Volume XXI, Special Issue 3, 73-83.

Kuznetsova, A.N., Rogachev, M.K., Sukhih, A.S. 2018. Surfactant solutions for lowpermeable polimictic reservoir flooding. Paper presented at the IOP Conference Series: Earth and Environmental Science, 194(4), doi:10.1088/17551315/194/4/042011.

Mill, J.S. 1980. Foundations of Political Economy. Moscow: Progress. - Vol. 1, p. 139.

Pankov, B.P. 2006. The socio-economic mechanism of regulation of the labor market in the village. Moscow, p. 146.

Rudoy, E.V., Shelkovnikov, S.A., Matveev, D.M., Sycheva, I.N., Glotko, A.V. 2015. Green box and innovative of agriculture in the Altai territory of Russia. Journal of Advanced Research in Law and Economics, Vol. 6, № 3, 632-639.

Romanov, A. \& Nikulin, A. 2016. Objectification of the assessment of individual skin erythema characteristics to determine the safe dose of UV impact on the human body. Research Journal of Pharmaceutical, Biological and Chemical Sciences, 7(3), 926-932.

Shelkovnikov, S.A., Kuznetsova, I.G., Poddueva, I.S., Hodos, D.V., Yakimova, L.A., Ganieva, I.A. 2016. Regulation of the labor market and human capital in the agrulture of the Novosibirsk region. International Journal of Economic Research, № 9, Vol. 13, 3829-3845.

Shelkovnikov, S.A., Kuznetsova, I.G., Denisov, D.A., Peshkova, O.O., Malyshev, Y.A. 2018. Enhancing the instruments of state support for the process of building human capital. International Journal of Civil Engineering and Technology, Vol. 9, Issue 8, 1633-1641.

Smirnov, L.P., Sukhovskaya, I.V., Borvinskaya, E.V. \& Kochneva, A.A. 2017. Some biochemical parameters of the transformation of xenobiotics in the freshwater pearl mussel margaritifera margaritifera. Biology Bulletin, 44(1), 24-27, doi:10.1134/S1062359017010137.

Stadnik, A.T., Shelkovnikov, S.A., Rudoy, Y.V., Matveev, D.M., Petukhova, M.S. 2015. Improving the methodology of disposition of state support funds for agriculture under the WTO rules. Asian Social Science, Vol. 11, № 14, 133-140. 